\title{
Diskurzusjelölő a periférián? \\ A szerintem véleményjelölő beszélt nyelvbeli pozícióiról ${ }^{1}$
}

\section{Bevezetés}

A mondatszint feletti, azaz az argumentumstruktúrától független, diskurzusszintü perifériák $^{2}$ valamelyikén elhelyezkedő elemek megnyilatkozásokat, beszédfordulókat kapcsolnak össze. ${ }^{3}$ A koherenciáért (is) felelős diskurzusjelölők jellegzetesen a bal periférián (BP) helyezkednek el, mint az alábbi példában a but az általa felvezetett he is honest tagmondathoz képest (Beeching-Detges 2014):

(1) He is a Republican, but he is honest. 'Republikánus, de öszinte'

Degandnak (2014) a beszélt nyelvre kidolgozott meghatározása alapján bal periféria alatt a megnyilatkozásnak az ige függőségi struktúráján kívüli, leginkább balra lévő helyét (slot) értjük, jobb periféria (JP) alatt pedig a leginkább jobbra lévő pozíciót (vö. ,a periféria fogalma a beszédegység vagy megnyilatkozás mindkét végére vonatkozik"; Onodera 2014: 93). Ez nem jelenti azt, hogy a BP-n elhelyezkedő elemek kizárólag megnyilatkozáskezdők lehetnek - bár jellemzően azok -, ahogyan azt sem, hogy a JP-n lévők mindig megnyilatkozászárók, ugyanis a diskurzusjelölök egymás mellett, akár társulva is megjelenhetnek mindkét periférián, és ez a helyzetüket befolyásolja. ${ }^{4}$ Az alábbi, a Beszélt Nyelvi Adatbázis spontán társalgásainak anyagából származó részletek a BP-n abszolút (2), illetve relatív kezdő (3), valamint a JP-n abszolút (4), illetve relatív záró (5) pozíciójú diskurzusjelölő-előfordulásokat példázzák: ${ }^{5}$

(2) IK: minket úgysem fog elönteni a víz szerintem van elég szárazföld körülöttünk ahhoz meg

B: hát ugyanúgy körbevesznek a hegyek (bea029)

(3) TP: kezdjünk megint neki az angol nyelv jó szövegnek

1 A tanulmány elkészültét az NKFI K-128810 számú pályázat támogatta.

A periféria fogalmáról bővebben lásd Beeching-Detges (2014) összefoglaló tanulmányát.

3 Vizsgálatunk alapegysége a megnyilatkozás (utterance), amely egy, néha több tagmondatból (clause) és az azokhoz kapcsolódó diskurzusjelölőkből áll, önmagában vagy más megnyilatkozásokkal együtt funkcionálhat beszédfordulóként (turn). Egy (tag)mondat egy (szabad határozókkal álló) predikátum-argumentum struktúrának felel meg (amelynek nem részei a diskurzusjelölők). A diskurzusszegmens kifejezés tetszőleges hosszúságú, de legalább egy tagmondatból álló beszédrészt takar.

4 Ehhez fontos hozzátenni, hogy megszólítások, indulatszavak, (nem diskurzusjelölőként azonosított) kötőszók is megelőzhetik őket, ekkor is csak relatíve kezdő helyzetüek tudnak lenni (vö. Traugott 2014: 73).

5 A példákban használt rövidítések: $\mathrm{B}=$ fö beszélő, $\mathrm{IK}=$ interjúkészítő, $\mathrm{TP}=$ társalgópartner (a 3. résztvevője a háromfös társalgásnak); központozást nem használtam, az esetleges átfedő beszédet zárójelekkel jelöltem. 
IK: $j a$

B: de egyébként szerintem a legkönnyebb (bea010)

(4) B: mondjuk akár magyarhoz akár a latin szövegek annyira nem változnak de azért oda is nyilván újítani kell meg az osztályt is figyelembe kell venni úgyhogy

T2: hát meg hogy mi érdekli nem (bea010)

(5) B: meg tényleg ostobák szerintem sajnos (bea166)

A perifériákat érintő kutatások egyik központi kérdése, hogy a bal és a jobb periféria milyen elemeket „vonz”, és mennyiben jár együtt sajátos jelentésekkel, illetve funkciókkal (Degand 2014). A tágan értett diskurzusjelölőket, mint fentebb láttuk, sokáig (szinte) csak a BP-n megjelenő, megnyilatkozáskezdő elemekként jellemezték (pl. Hansen 1997; Fraser 1999). Változatos - textuális, interperszonális, attitüdjelölő funkcióik, amelyek egyazon jelölö akár egyazon aktuális használatára is jellemzők lehetnek, ugyanakkor azt a kérdést vetik fel, hogy ezek a különböző szerepek menynyiben kapcsolódhatnak a kezdő, illetve az attól eltérő pozíciójú használataikhoz.

A diskurzusjelölők JP-n való megjelenése ugyan jóval ritkább, mint a BP-n Fraser (1999) még kivételesnek tartotta -, de egyes diskurzusfunkciók, például a szekvenciális szerepeken belüli záró határvonal jelzése, amely egyúttal a szó átadása vagy annak jelzése, kizárólag a JP-n történhet meg általuk (Degand 2014; vö. Dér 2012; a diskurzusjelölö-funkciókat részletesen lásd Crible 2018: 47). A beszédtervezés egyéb sajátosságai miatt a beszélők gyakran utólag adnak hozzá információkat az általuk elmondottakhoz, ez is eredményezheti ezeknek az elemeknek a JP-re kerülését (Crible 2018: 45).

Szekvenciális funkciók alatt a diskurzusstrukturálást, a diskurzusszegmensek egymáshoz való sorrendjének a megadását, illetve a témairányítást értjük, ez a társalgások esetében a beszédirányítást (kinél van/lehet a szó) is magában foglalja. González (2004) szerint közéjük tartozik a diskurzusszegmensek határainak jelzése, a diskurzushálózat fenntartása, így a szegmenskezdés és -zárás, az idézés jelzése, valamint a cselekményfejlődés felvezetése. Crible (2018) a szekvenciális funkciók között említi a tagolást, a nyitó és a záró szegmenshatár jelzését, a témaváltást, a korábbi témához való visszacsatolást, az idézést, a hozzáadás és a felsorolás jelölését (lásd még Furkó 2019; Dér 2020).

A diskurzusjelölők sokat emlegetett multifunkcionalitása jól tetten érhető a BP és a JP legszélén álló példányaik esetében: az ilyen elemek közül sok - egyéb ideációs, retorikai és interperszonális funkciói mellett, ha vannak - sokszor valamilyen szekvenciális szerepet is hordoz. Sokan egyenlőségjelet tesznek a relációt kifejezni képes diskurzusjelölők és a kötőszói (connective) jelölők közé, ugyanakkor nem csak utóbbiakat találjuk meg az elöbbiek között: Crible a nyitó szegmenshatár jelölöi között említi az angol I mean 'úgy értem', okay 'oké, rendben', right 'rendben, jó' elemeket, melyek egyike sem kötőszói. A nem relációs diskurzusjelölök (pl. you know 'tudod', sort of 'egyfajta, valamiféle, valahogy') nem két diskurzusszegmens közti viszonyt jelölnek, hanem csak egy egység felett rendelkeznek hatókörrel (Crible 2018: 35). Az I think 'azt hiszem; szerintem' diskurzusjelölöt - amely az általunk 
vizsgált szerintem egyik lehetséges angol nyelvü megfelelője - nem tartja relációsnak Degand-Simon-Vandenbergen (2011), Crible pedig átmenetisége miatt nem is vette fel a diskurzusjelölök közé (Crible i. m.).

Traugott (2014) megközelítésében a nyelvi elemek perifériára kerülése azok jelentésének egyre (inter)szubjektívebbé válásával, azaz (inter)szubjektivizálódással jár(hat) együtt, ugyanakkor a diskurzusjelölők eleve (inter)szubjektivitást ${ }^{6}$ kifejező $^{\prime}$ elemek. A BP-n való elhelyezkedésük elsősorban a szubjektív (argumentatív - azaz kauzális, feltételes, konkluzív stb. -, episztemikus, információstrukturáló, válaszjelölő, figyelemnyerő), a JP-n pedig az interszubjektív (metatextuális, interperszonális, interakciós, választ serkentő) szerepkörökkel kapcsolható össze (uo., vö. Degand 2014: 159).

A beszélő vélekedését explicitté tevő, szubjektivizációt kifejező véleményjelölők kategóriája igen komplex a magyarban: Kugler szerint evidencialitást, azon belül beszélöi értékelést, ugyanakkor az esemény valószínüségét megadva episztemikus modalitást is kifejezhetnek. A két rendszer nem különül el, ezért nevezi a két tartomány kifejezését összevonva episztenciálisnak. Olyannyira nem, hogy az eddigi kutatások alapján az egyes elemek, így a vizsgálatunk fókuszában álló szerintem esetében sem voltak élesen elhatárolhatók egymástól a valószínüsítést, illetve a szubjektív értékelést kifejező változatok, bár valamelyik jobban elötérbe kerülhetett (Dér 2018; Kugler 2015).

A szerintem modális használatai a diskurzusjelölö-funkciók közül elsősorban a retorikai struktúrához kapcsolódó szerepekhez köthetök (Crible taxonómiájában pl. a kommentálás, a konklúzió és a hangsúlyozás funkciókhoz; Crible 2018). Interperszonális müködését az egyetértésekben vagy egyet nem értésekben, valamint az arcmunkában (Brown-Levinson 1987) figyelhetjük meg. A magyar beszélök egy vizsgálat tanúsága szerint éppen a kezdő és nem a záró pozíciójú szerintem-et asszociálták magasabb fokú udvariassággal - önmagában és az azt hiszem asszem véleményjelölő mindkét változatához képest is (bővebben lásd Dér 2020: 189-218).

Beeching és Detges (2014: 11) az angol I think 'azt/úgy hiszem/gondolom; szerintem' BP-n való használatát az I think he 'll be there példán szemléltetve úgy jellemzi, mint amelynek a révén a beszélö szubjektív ítélete kerül előtérbe, míg a JP-n (He'll be there, I think) ez a háttérben marad, és a diskurzusjelölö enyhíti az állítás erejét.

Mullan (2010) az I think három diskurzusfunkcióját emelte ki: 1) a leggyakoribb az organizációs, mint például a határjelölés, az új téma/perspektíva bevezetése; 2) a szemantikai, ezen belül két eset lehetséges: az I think kifejezhet kételyt, amikor a beszélő bizonytalan a propozíció érvényességét vagy igazát illetően, esetleg hiány-

6 Szubjektivizálódás (subjectification): az a szemantikai folyamat, amelynek során a jelentés egyre inkább a beszélő vagy író szubjektív hiedelmeit, álláspontját vagy attitüdjét kezdi el kódolni a megnyilatkozás propozicionális tartalmát illetően (Haselow 2012; idézi Beeching-Detges 2014: 7). Interszubjektivizálódás: amikor a jelentés - az előbbi folyamatban továbbhaladva - egyre inkább a beszélőnek/írónak a hallgató/olvasó szelfjére utaló figyelmét kódolja mind episztemikus, mind társas értelemben, tehát figyelemmel a befogadó feltételezett attitüdjeire és arcára (Traugott 2003; idézi Onodera 2014: 93). 
zik valami a tudásából; illetőleg kifejezhet vele véleményt, azaz egy téma szubjektív értékelését. A 3)-as a pragmatikai funkció: az arcvédés.

Detges és Waltereit (2014) szerint a közbevetésként (parentheticals) is kategorizálható francia (moi) je trouve que... 'azt hiszem; szerintem' és idegen nyelvü megfelelői tipikusan a beszélői érvelés kulcsmozzanatát vezetik fel, így metapragmatikai operátorként foghatók fel, amelyek mitigálhatnak és erősíthetnek is a kontextuális tényezőktől és más diskurzusjelölök megjelenésétől függően (ezt a magyarban is vizsgáltam a szerintem kapcsán; lásd Dér 2020). Állításuk szerint általánosan igaz, hogy a BP-n megjelenő elemek lehorgonyozzák (anchoring) a soron következő rémát vagy az általa kifejezett illokúciót, a JP-n lévők révén az illokúció és a réma újratárgyalható (re-negotiation). Úgy vélik, az interszubjektivitás nem köthetö csak a JP-hez, mindkét periféria hordozhat modális és a koherenciához kapcsolódó funkciókat. A két periféria egyébként meglévő funkcionális aszimmetriáját a beszéd időbeli linearitásával magyarázzák: a BP az üzenet kezdetét jelzi, ezért alkalmas a következő megnyilatkozást a megelőző megnyilatkozáshoz vagy a beszélőhöz magához kötni; a JP az üzenet vége, amely ekkortól kommentálható, illetve e helyütt fejezhető ki elvárás a hallgató felé (ritkábban pedig a javítások helye).

A szerintem gyakoriságára és pozíciójára vonatkozó korábbi elemzések szerint az MNSZ2 adatbázisbeli több mint 250 ezer elöfordulás csaknem $60 \%$-a a személyes-fórum alkorpuszból származott, ezt követte több mint 20\%-kal a beszélt sajtónyelv. A harmadik helyen álló személyes-közösségi alkorpusz kb. 17\%-át is tekintve a szerintem megjelenéseinek háromnegyede az írott beszélt nyelvet reprezentáló személyes regiszterben adatolható (Dér 2020). Az ugyanezen adatbázisból származó százelemü véletlen minta elemzése azt mutatta, hogy a véleményjelölő 65\%-ban (abszolút) kezdő pozíciójú (tehát a BP-n jelenik meg), 18\%-ban belső (mediális), és csak 16\%-ban záró helyzetü (JP). A BEA négyféle spontánbeszéd-anyagából (interjú, véleménykifejtés, társalgás, interpretált beszéd) létrehozott alkorpuszra irányuló elemzés szerint az írott és az írott beszélt múfajokhoz képest a spontán beszélt nyelvre jellemzőbbnek látszik a belső pozíció (csaknem 27\%) (Dér 2016).

A belső pozíció nem köthető perifériákhoz, az elemnek a mondatstruktúrán belüli megjelenését takarja. Ez azonban nem jelenti azt, hogy szükségszerüen része is annak: a szerintem a módosítószókhoz hasonlóan nem mondatrészként funkcionál, nem része a mondat szerkezetének, hagyományos grammatikai felfogásban elöre-, hátra-, illetve - mondatbelső helyzetben - közbevetésként értelmezhető (Kugler 2000: 299; vö. a parentheticals kategóriával fentebb). Strukturális keretben az ilyen elemeket mondathatározóknak tartják, amelyek a topik elött és után is helyet foglalhatnak, és hatókörük az egész állításra kiterjed (É. Kiss 1992).

Traugott (2014: 74) az angol surely és no doubt EPA-k (Epistemic Stance Adverbials, episztemikus álláspontot jelölő határozók) kapcsán említi, hogy tagmondaton belüli (mediális) pozíciót is felvehetnek, ahol a propozíció általánosan tudott igazság voltát hangsúlyozzák. Ekkor mondat feletti hatókörrel rendelkeznek, nem diskurzus felettivel.

A vizsgálat arra a fó kérdésre keresi a választ, hogy a szerintem véleményjelölő milyen (pragmatikai) pozíciókat vehet fel a spontán társalgásokban és (fél)spontán 
interjúkban, és ezek milyen összefüggést mutathatnak modális funkcióival. A társalgások szervezésében betöltött szerepét is elemezve a kutatás feltárja, hogy lehetnek-e szekvenciális funkciói, tehát mennyiben használatos szóátadó és -átvételi szerepben. Tisztázza, hogy a belső pozíciójú megjelenések esetében milyen a hatóköre, a belső helyzeten belül mutat-e a pozíciója bármilyen szisztematikusságot (mivel az többféle mondatrész előtti vagy utáni pozíciót megenged). Ebből fakadóan azt az alapvető kérdést is meg kívánja válaszolni, hogy kizárólag a BP-n és a JP-n lévő megjelenései tekinthetőek-e diskurzusjelölőnek, vagy pedig a belsők is.

A korábbi kutatások alapján a következő hipotézisek fogalmazhatók meg:

H1a. A társalgásokban a szerintem kezdő előfordulása lesz a leggyakoribb, ezt követi a belső, végül a záró.

H1b. A rádióinterjúkban arányában kevesebb lesz a belső pozíciójú előfordulás (az abszolút kezdő és kezdő helyzet javára).

$\mathrm{H} 2$ : Azt várom, hogy a szerintem BP-n való megjelenése esetében a vélekedésen belül inkább az episztemikus funkciója, a valószínűsítés kerül előtérbe, a JP-n tartózkodva inkább az értékelő.

H3: A szerintem (abszolút) kezdő pozíciójának túlsúlya miatt inkább szóátvételkor lesz használatos, szóátadáskor kevéssé vagy nem. Mivel vélekedésjelölő szerepe a meghatározó, szekvenciális funkciói periférikusak.

\section{Anyag és módszer}

Az elsőként elemzett anyagot a Beszélt Nyelvi Adatbázis negyven, mindennapi témákról szóló spontán társalgása képezi, ${ }^{7}$ amelyben két korosztály (20-30, illetve 40-55 év köztiek) és mindkét nem (10 fiatal és 10 idősebb nő, 10 fiatal és 10 idősebb férfi) reprezentálta magát. A társalgások hossza összesen 11 óra 49 perc volt (nemenkéntkorcsoportonként az időtartamuk a következőképpen alakult: fiatal férfiak: 3 óra 41 perc, idősebb férfiak: 2 óra 40 perc, fiatal nők: 2 óra 47 perc, idősebb nők: 2 óra 42 perc).

A szerintem-elöfordulásokat a Praat 6.1.1.14 verziójú szoftver segítségével, illetve a társalgások többszöri lehallgatásával azonosítottuk, ${ }^{8}$ kigyüjtésüket követte pozícióik és lehetséges funkcióik meghatározása. A statisztikai próbákat az SPSS 26.0-s verziójával végeztük.

A második vizsgálat az MNSZ2 beszélt nyelvi, azaz rádióinterjúkat tartalmazó alkorpuszából származó 500 találatos véletlen mintán történt, a szerintem keresőkifejezést lekérdezve. ${ }^{9}$ A találatokat manuálisan elemeztem, négy pozíciót vettem fel ( $\mathrm{AK}=$ abszolút kezdő, $\mathrm{K}=$ kezdő, $\mathrm{B}=$ belső, $\mathrm{Z}$ = záró, meghatározásukat

7 A BEA jellemzőit részletesen lásd Gósy Mária - Gyarmathy Dorottya - Horváth Viktória - Gráczi Tekla Etelka - Beke András - Neuberger Tilda - Nikléczy Péter 2012; illetve Dér 2020: 33-6.

8 E munkák oroszlánrészéért köszönettel tartozom Huszár Annának.

9 A lekérdezés ideje 2021. június 30. volt. 
bővebben lásd a 3.1. fejezetben). Mivel az interjúk hangzó anyagához az adatbázisban nem lehet hozzáférni, csak az írott változatú lejegyzéseikhez, mindig a lejegyző központozásából indultam ki a pozíció megállapításánál (a példákban ezek betühü változatát adom meg, tehát elgépelésekkel, hibákkal együtt), a nem egyértelmüen megítélhető eseteket töröltem a vizsgálatból. A végleges elemzésbe összesen 487 előfordulás került be.

\section{A BEA-társalgások elemzésének eredményei}

A negyven társalgásban összesen 166 darab szerintem-elöfordulást lehetett regisztrálni, ebből 98-at férfi, 68-at női adatközlöktől; 116-ot a fiatal, 50-et pedig az idősebb beszélőktől.

A korábbiakban már említett abszolút és relatív kezdő kategória a következőket fedte: abszolút kezdő pozíciójúnak vettem a jelölőt, ha a bal periféria első helyét foglalta el, akár beszédfordulóról, akár megnyilatkozásról volt szó, kezdőnek pedig akkor, ha a bal periférián az első diskurzusjelölő elem utáni második helyet foglalta el (ha viszont két diskurzusjelölő előzte meg, akkor a harmadikat). Záró pozíciójúnak vettem minden abszolút és relatív záró helyzetű elemet, vagyis ha a jobb periféria legutolsó vagy utolsó előtti helyét foglalta el a szerintem (diskurzusjelölő még követhette). Belső helyzetűnek vettem minden, az előbbiektől eltérő, nem újraindított vagy félbeszakított közlésbeli előfordulást.

Mint az 1. ábrán látható, a BP-n helyezkedett el a szerintem elöfordulásainak több mint 60\%-a, csaknem egynegyede pedig belső pozíciójú volt. Figyelemre méltó, hogy a relatív kezdő helyzet dominált (több mint kétszerannyi találattal, mint az abszolút kezdő), vagyis a BP-n megjelenő szerintem-et jellemzően megelőzi egy másik dis-

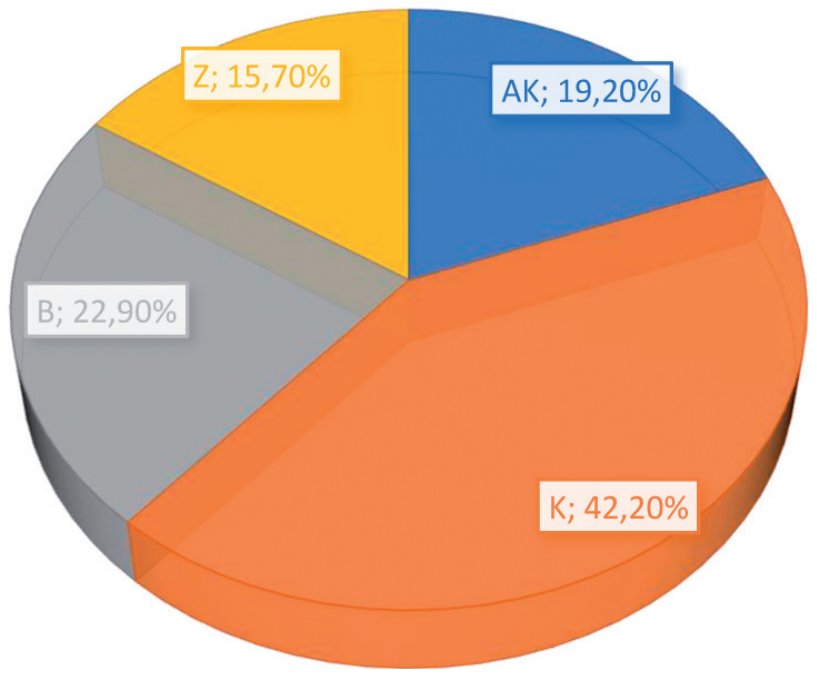

1. ábra. A szerintem pozíciói a BEA-társalgásokban ( $\mathrm{AK}=$ abszolút kezdő, $\mathrm{K}=$ kezdő, $\mathrm{B}=$ belső, $\mathrm{Z}=$ záró $)$ 
kurzusjelölő (és, meg, de, tehát, hát, na hát, igen de, mert, egyébként, mondjuk).

Az alábbiakban az összes pozícióra hozok példát.

Abszolút kezdő - beszédfordulókezdő:

(6) TP: én csak ebben tudok reménykedni

IK: hát igen...

B: szerintem ez azért nem annyira általános, hogy minden szülö ilyen fiatalon ennyire elengedi (bea147)

Abszolút kezdő - megnyilatkozáskezdő:

(7) B: nem vagyok munkamániás, nekem muszáj dolgozni szerintem egy emberek elég nagy többségének muszáj dolgozni, különben nem tud mit enni (bea034)

Kezdő:

(8) B: ahogy már beszéltünk itt morális válságról az er-erkölcsi színvonal is nagyon sokat zuhant és énszerintem ennek mindenképpen köze van hozzá (bea147)

Belső:

(9) B: hát azér egy szakember szerintem jobban felméri hogy milyen fal tehát hogy egy ilyen $m$ húsz centis vál-válaszfal mer ez nem ööö tartófal (bea175)

Relatív záró:

(10) B: hát ezt ezt tüdőből ez... még most is izomlázas lennék szerintem úgyhogy

IK: biciklipumpa (bea170)

Záró:

(11) B: meg meg meg a divat is egyre elrugaszkodottabb szerintem tát ezér is nehéz például ajándékokat venni (bea331)

Mind az előfordulások összességét, mind az egyes pozíciókat nézve a férfiak produkáltak több szerintem-et (2. ábra), a legnagyobb különbség a záró pozícióban mutatkozott a javukra.

A 3. ábra a fiatalok előnyét szemlélteti a szerintem mindegyik pozíciójában. Különösen látványos az eltérés a belső pozíciót illetően.

Jól láthatóan a fiatal férfiak használták a legtöbb szerintem-et mindegyik pozícióban (4. ábra) - ugyanakkor egy vagy több sokat beszélő adatközlő önmagában is vezethet ilyen eredményekre. Ez valóban így is volt, a bea179-es adatközlő egymagában 39-szer használta a szerintem-et, ami a férfiak összes szerintem-előfordulásának a $39,8 \%$-a, a fiatalokénak pedig a 33,6\%-a volt. 


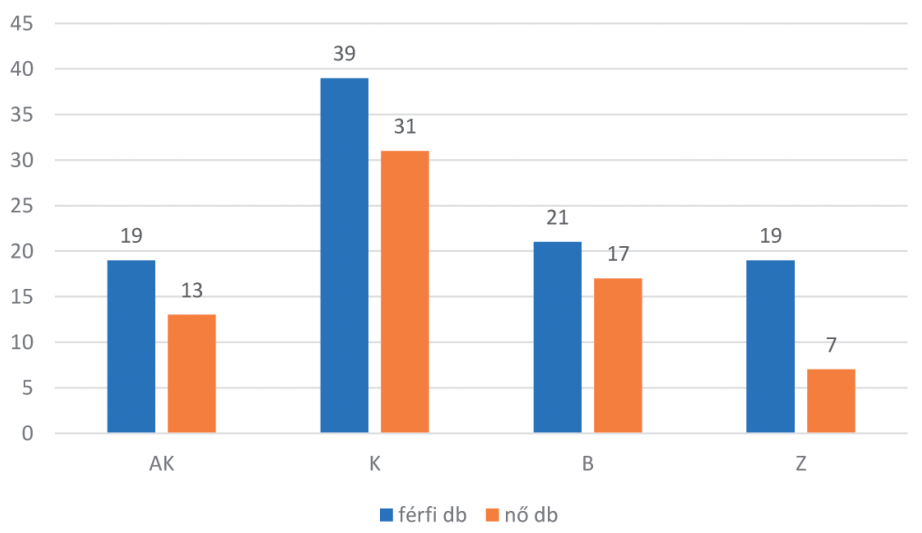

2. ábra. A szerintem előfordulásai (db) pozíciók és nemek mentén a BEA-társalgásokban

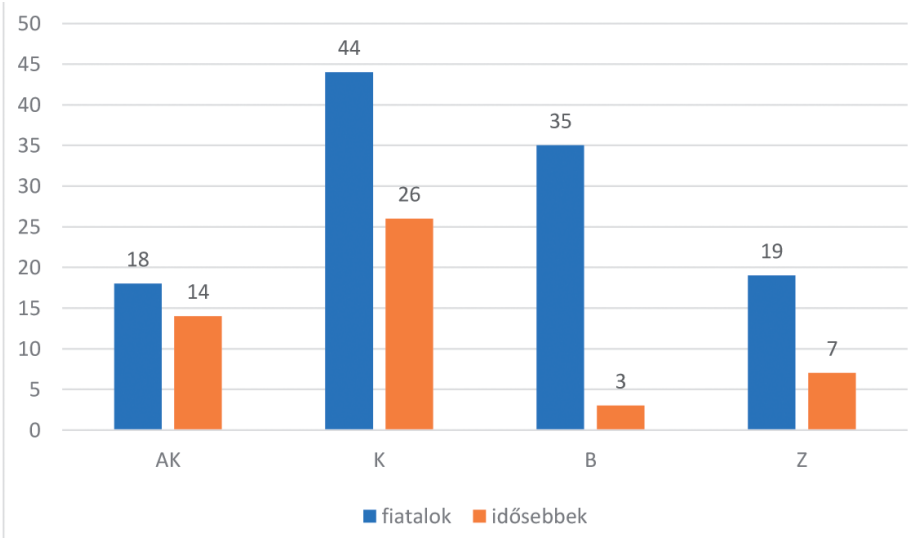

3. ábra. A szerintem előfordulásai (db) pozíciók és kor mentén a BEA-társalgásokban

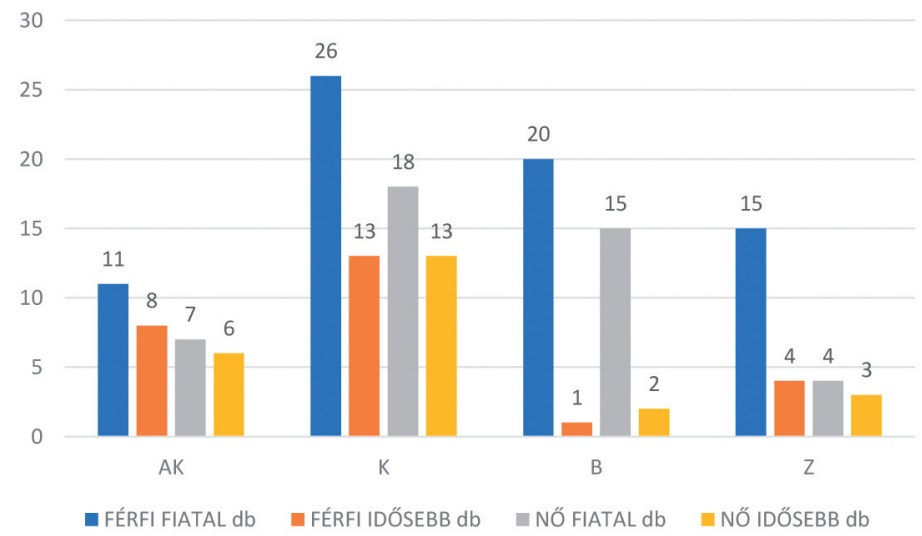

4. ábra. A szerintem pozíciói nemek és korok mentén a társalgásokban 
Az elvégzett khí négyzet próba $\left(\chi^{2}=2,664 ; d f=3, p>0,1\right)$ megmutatta, hogy nem szerint nem volt szignifikáns eltérés a pozíciókat illetően, kor szerint azonban igen: a fiatalabbak az összes pozícióban szignifikánsan gyakrabban használták a szerintem-et. Kétféle elemzés történt erre vonatkozóan: az elsőben az AK és a K kategóriát nem vontam össze $\left(\chi^{2}=13,509, \mathrm{df}=3 ; p<0,05\right)$, a másodikban a bal perifériát egységesen néztem $(\mathrm{AK}+\mathrm{K})$, a különbség itt is jelentős volt a két korcsoport között $\left(\chi^{2}=13,053 ; \mathrm{df}=2, p<0,05\right)$.

A 38 darab belső (mediális) szerintem-et az explicit alanyhoz és az állítmányhoz (mint a mondat magjához, az állítást hordozó részhez) képest elfoglalt helyzete szerint 5 csoportba soroltam be:

- közvetlenül alany elötti pozíció ( $2 \mathrm{db})$, például:

(12) B: attól függetlenül hogy végig nagyon élveztem de de de égettem is a kalóriákat rendesen azér' a szinpadon meg a lámpák alatt szerintem ez teljesen alap (bea179)

- közvetlenül állítmány elötti pozíció (7 db), például:

(13) B: nem tudom hogy hogy jutottunk el idáig egyszerüen az emberek szerintem ostobák igy mondjuk a nagy része vagy tényleg hülyék (bea166)

- közvetlenül állítmány utáni pozíció (11 db), például:

(14) B: mindenképpen jobb szerintem is egy személyes ajándék (bea017)

- közvetlenül a névszói állítmány névszói része előtti pozíció ( 6 db), például:

(15) B: szóval ez ez szerintem egy hiányos dolog (bea113)

- egyéb pozíció (12 db), például:

(16) B: ilyen nagy okosságokat szerintem erröl nem lehet mondani (bea149)

Ez alapján megállapítható, hogy a mediális szerintem az esetek csaknem felében közvetlenül megelőzte vagy követte az állítmányt. ${ }^{10}$ Fontos azonban megemlíteni, hogy 17 eset (a belső elöfordulások 44,7\%-a) a már említett, nagyon hosszú társalgásban részt vevő bea179 beszélőtől származott, aki túlnyomórészt az állítmány előtt/után használta a szerintem-et.

A belső pozíciójú szerintem-használatok mindegyike a teljes propozícióra vonatkozott, ezt tekintve tehát a véleményjelölö bármelyik említett helyzetben megjelenhet; az eredeti (17a) megnyilatkozásbeli szerintem hatóköre BP (17b) és JP (17c) helyzetben is ugyanaz:

${ }^{10}$ Ez a kezdő és záró pozíciókban is lehetséges, de ezeket most nem vizsgáltam ilyen szempontból. 
(17a) nem lehet szerintem aláfestésnek Wagnert hallgatni sehol (bea179)

(17b) szerintem nem lehet aláfestésnek Wagnert hallgatni sehol

(17c) nem lehet aláfestésnek Wagnert hallgatni sehol szerintem

Megvizsgáltam, hogy a szerintem BP-n és JP-n elhelyezkedő változatai esetében megfigyelhető-e különbség a funkciókat illetően, vagyis azt, hogy igaz-e az a feltevés, miszerint (abszolút) kezdő pozícióban (BP) a véleményjelölö használata inkább episztemikusabb (inkább valószínüsítést fejez ki), míg záróban (JP) interszubjektívebb, inkább értékelést ad vissza.

A záró pozíciójú (JP) előfordulások mennyisége (26 db) csak a negyede volt a BP-sekéhez képest (AK+K: $102 \mathrm{db})$, így alábbi megállapításaink korlátozott érvényünek tekinthetök.

Mivel együttes, episztenciális rendszerről van szó, tehát a vélekedésjelölők egyaránt visszaadhatnak értékelést és valószínüsítést is, ez a képességük egyazon aktuális használatukra is jellemző. Vagyis a két szerepkör általában egyáltalán nem választható szét. Ezt tapasztaltuk a szerintem esetében is: bár voltak esetek, amikor inkább az értékelő (18) vagy éppen az episztemikus jelleg (19) tűnt meghatározónak, rendszerint mindkettő egyszerre volt jelen (20). ${ }^{11}$ Ez igaz volt mindkét vizsgált periféria esetében - az alábbi példák révén ezt a JP esetében mutatjuk meg:

(18) B: tehát azért úgy teljesen meg lehet állapitani szerintem, hogy ki a bölcsész és ki a müegyetemista (bea169) - itt a teljesen miatt (is) valószínüsíthetőbb az értékelés

(19) B: utána már könnyebb a gyakorlatot megszerezni szerintem, mint csekély tudással (bea043)

(20) B: és egy idő után mindenkinél elszakad a cérna szerintem (bea166)

A lehetséges szekvenciális szerepek meghatározásához a szerintem összes BP-n és JP-n belüli abszolút fordulókezdő és záró fordulópozíciójú megjelenését többszöri meghallgatás után, egyenként elemeztem (tehát a nem fordulókezdő és -záró AKpozíciójúakat nem). A 32 AK-elöfordulásból összesen hat esetben volt fordulókezdő az elem (két adatközlö kétszer is használta), például:

(21) TP: a srácnál ilyen nem matekoldalon jött ki, hanem humán oldalon

B: szerintem nincs egyébként matek és humán oldal

TP: jó, én erre szavazok (bea179)

Ezek vegyes képet mutattak a beszédirányítás szempontjából: volt benne ön- és külkiválasztás, a szó erőteljesebb magához ragadása (közbevágás) és egyezkedőbb szó átadás-átvétel is. Egy ízben az éppen hallgató szerepben lévő fő adatközlő (B) kétszer is szerintem-mel próbálta átvenni a szót a beszédjoggal rendelkező féltől (IK), ami egy kis időre sikerült is neki - ennek feltehető oka az volt, hogy a közlése

${ }^{11}$ De ha az egyik erősebb is, ettől még a másik funkció is jelen van valamilyen mértékben, a két funkció közti tartomány kontinuumszerüen fogható fel. 
háttércsatorna-jelzésként is felfogható volt -, ám azt utána az eredeti beszélő vette vissza:

(22) IK: pedig az egy tök jó ötlet

B: szerintem is...

IK: (már hogy nem azé, hanem)

B: (szerintem is de)

IK: (fenyitésnek) tök jó (bea032)

Az összesen 26 darab JP-ú előfordulásból négy olyan van, amely abszolút fordulózáró helyzetü, például:

(23) B: az még nem büncselekmény szerintem

IK: aha, mer egyébként annyira fura, hogy ugye én most egy csomó mindent igy a jutúbon találtam meg (bea276)

Volt néhány olyan eset, amikor a beszélő átadta volna a szót (ezt a hosszú néma szünet vagy hezitálás jelezte), de mivel senki sem vette át tőle - vagy mert senki nem szólalt meg, vagy mert csak háttércsatorna-jelzést adott -, folytatta (ezeket nem soroltam be a szóátadó kategóriába, csak azokat, amelyeknél a szóátvétel meg is történt), például:

(24) B: neveléssel, hát mindenképpen neveléssel szerintem meg hát ha az iskola színvonala is visszakapná a régi színvonalát (bea147)

Azt láthatjuk tehát, hogy a szerintem szekvenciális szerepe igen szerény: az elem elenyésző számban jelentkezik fordulók elején és végén ilyen funkciókban; sokkal jellemzőbb rá, hogy ha záró helyzetben van, a beszélő folytatja utána a mondanivalóját, például:

(25) B: és mondjuk nem olyan rossz hogy a tizenkét éves korára már mondjuk programot tud irni szerintem mert mert akkor ugye ebbe nöl bele (bea170)

\section{A rádióinterjúk elemzésének eredményei}

Az MNSz2 (fél)spontán ${ }^{12}$ dialógusokat tartalmazó rádióinterjúinak átiratából származó 500 véletlen találat elemzése a szerintem BP-n való dominanciáját mutatta (5. ábra): az abszolút kezdő ( $167 \mathrm{db}$ ) és a kezdő (120 db) előfordulások adták az ösz-

${ }^{12}$ Félspontánnak tekinthető a rádióinterjú müfaja, mivel az azt készítő riporter előzetesen készül, az interjúalany azonban nem vagy nem szükségszerüen, az ő részéről spontánabb megnyilatkozások születnek. Háromoldalú kommunikációs helyzetnek szokás az interjúhelyzetet tartani, mivel a résztvevők a beszédpartneren kívül a közönséghez is igazítják beszédüket (Boronkai 2012). 
szes találat csaknem 60\%-át. Figyelemre méltó, hogy az AK-esetek kétharmada (108 eset) fordulókezdő volt, ezt magyarázza, hogy ezek az interjúk sokszor kérdés-válasz építkezésủek. Az interjúalany véleményére, gondolataira rákérdező riporternek adott válasz így gyakran indul véleményjelölővel, például:

(26) Mv: - Az oktatási jogok biztosaként, a gyermekek jövőjéért felelösként mit gondol, mennyi idö alatt érhetnek be ezek a kezdeményezések, mert hát hiszen azért ez tudati és életmódbeli változást is igényel.

Aáry Tamás Lajos: - Szerintem, be kéne vonni a gyerekeket. (MNSz2, \#856679458,doc\#2599,spok_hu_radio_002)

Abszolút kezdő - megnyilatkozáskezdő: ${ }^{13}$

(27) Rip. - Négy gyözelem után nyilatkozott. Ebböl a négyböl, azért elevenitsünk fel valamit. Melyik volt a legemlékezetesebb?

- Szerintem kettö is volt. Az észak-koreai ellen, amikor meglett a kvótám, és illetve a mongol ellen, amikor bejutottam a döntőbe. (MNSz2, \#860867792,doc\#2602,spok_hu_radio_005)

Abszolút kezdő - tagmondatkezdő:

(28) Eörsi Mátyás: - Én nagyon-nagyon régóta képviselem azt az álláspontot és arra kérem politikustársaimat, nemcsak Magyarországon, hanem az Európai Unió más tagállamaiban is, hogy amikor az Európai Bizottság hoz egy döntést, ne takarózzanak azzal, hogy ezt a döntést ránk kényszeritették, ez nem jó, ettöl senki nem tudja a döntést elfogadni, ettöl csak haragudni fognak az európai intézményekre, szerintem minden egyes politikusnak, függetlenül attól, hogy kormányon van, vagy ellenzékben van, meg kell tudnia érdemben magyarázni ezeknek a döntéseknek a hátterét, amikor az Európai Bizottság hoz egy döntést a magyar elektromos ágazattal kapcsolatban, ezt nem a magyarok ellen hozza. (MNSz2, \#859995667, doc\#2601, spok_hu_radio_004)

Kezdő:

(29) Rip: Hogy fogadta a hírt, mikor meg tudta, hogy mit csináltak? „Hazajött a kisgyerek és mesélte, akkor megdicsértem, utána, hogy jöttek sorban a telefonok, hát nagyon örültem neki, hogy ilyen ügyesen cselekedtek, ilyen gyorsan reagáltak a dolgokra, és a helyes úton döntöttek. Úgy gondolom szerintem, hogy én sem hagytam volna ott." (MNSz2, \#869540339,doc\#2607,spok_hu_radio_010) - egy másik vélekedésjelölöt (úgy gondolom) követ.

${ }^{13}$ Az átiratok központozása lehetővé tette a (beszéd)fordulókezdő, megnyilatkozáskezdő, illetve tagmondatkezdő előfordulások megkülönböztetését. 
A belső helyzetű használatok a találatok egyharmadát tették ki, a zárók pedig kevesebb mint az egytizedét. Lássunk példát ezekre is:

Belső:

(30) Rip. - Csak sikerült neki?

Telef: - Nem sikerült. Nem, nem, és akkor beszélgettünk róla, hogy vajon miért nem, azt mondja, hogy igazából olyan szinten beszéltek a vizsgáztató tanárok angolul, mint egy átlagos középiskolás, ott követte el szerintem a hibát, hogy egy-két tévedésüket kijavitotta, és ettöl kezdve, nem ment át a szóbelin, meghallgatásra. (MNSz2, \#856121295,doc\#2599,spok_hu_ radio_002)

Záró:

(31) R: - Mi az, hogy szerintem 5?

Körülbelülre mondom, hogy nevüket nem tudom, csak kettönek. Mert úgy állunk az egy éjszakás kalandokhoz, hogy nem szerelem lesz belöle szerintem. (MNSz2, \#863717760,doc\#2604,spok_hu_radio_007)

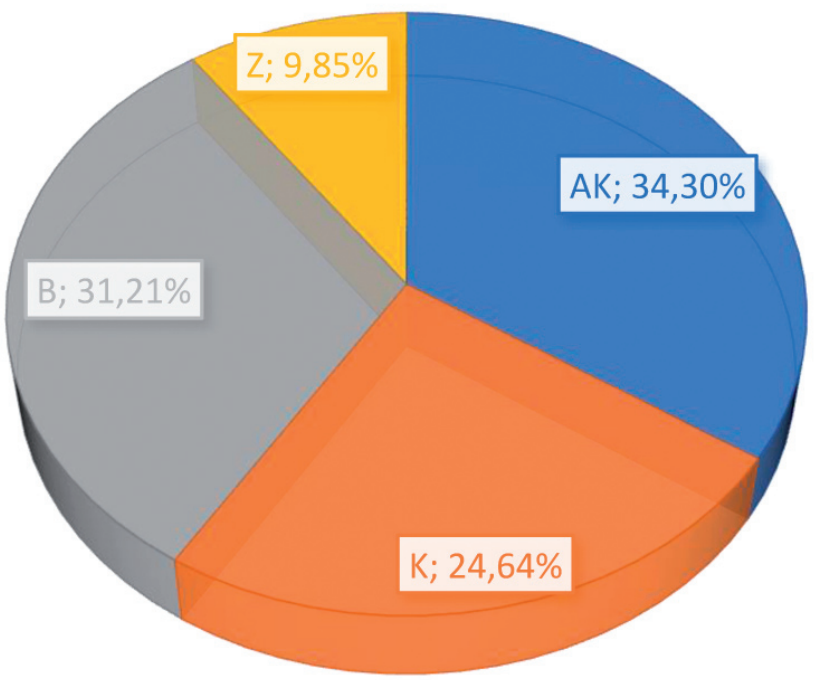

5. ábra. A szerintem pozíciói a rádióinterjúkban

Kezdő pozícióban összesen 20-féle diskurzusjelölö-típust (illetve a hogy kötőszót) követte a szerintem, amelyek közül a leggyakoribbak az és, de, akkor, tehát és hát voltak, vagyis a hát-ot leszámítva a müfajfüggetlenül jelentkezö, önmagában is legfrekventáltabb jelölők mögött jelentkezett, például: 
(32) Szlavkovics Rita: - Most mondja, egyébként mit gondol, hogy minek köszönheti?

- Hát ma aztán végképp nem mondható el az, hogy nagyon örömködnének a vállalkozások, de szerintem ez az elmúlt évekre mindig is igaz volt. (MNSz2, \#927517564,doc\#2645,spok_hu_radio_048)

(33) Sz. I.: - Én úgy érzem, hogy rossz kezdés ellenére a befejezés az nagyon jól sikerült és szerintem egyértelmü győzelem volt. (MNSz2, \#935325232,doc\#2650,spok_hu_radio_053)

A szerintem belső pozíciójú (151 db) előfordulásai az alábbi megoszlást mutatták:

- közvetlenül alany előtti pozíció (7 db), például:

(34) Rip. - Tulajdonképpen mennyi volt a legnagyobb kilengés? Most mondtam egy értéket a beszélgetés elején, ez 6.5 százalék, ez egy átlag, ugye a tavalyi évre vetitve. Mi volt a legkevesebb, és mi volt a legtöbb?

Fóris Sándor: - A legrosszabb éve a nyugdijpénztári ágazatnak, az 2000 volt, 2003 és most szerintem 2008 lesz az. (MNSz2, \#885098065,doc\#2617,spok_hu_radio_020,beszéltnyelv)

- közvetlenül állítmány elötti pozíció (11 db), például:

(35) Ha csak egy elöadás erejéig katedrára álltak, akkor is az a kisugárzás, szakmai hozzáállás azért szerintem beépült a hallgatók tudatába és úgy tudom hogy 35-en végeztek és ebböl 5-6-an nem dolgoznak a sajtóban akik nem is igazán akartak a sajtóban dolgozni. (MNSz2, \#933873289,doc\#2649,spok_hu_radio_052)

- közvetlenül állítmány utáni pozíció (18 db), például:

(36) R.: - Tehát érdemes volt végigcsinálni?

Hát ahhoz képest, amilyennek gondoltam, teljese más lett, és elég jókat beszélgettünk szerintem ezekröl a dolgokról. (MNSz2, \#877341258,doc\#2612,spok_hu_radio_015)

- közvetlenül a névszói állítmány névszói része előtti pozíció ( 3 db), például:

(37) Cservenka Judit: - Amikor Bánk bánt énekelt mindig ezt az eredeti változatot?

Marton Éva: - Nem, nem. Ennek több fajta változata van. Ugye az operaházban is a Nádasdi féle változat ami szerintem az egyik legjobb. (MNSz2, \#853072287,doc\#2597,spok_hu_radio_000)

- egyéb pozíció (130 db, részletesen lásd lentebb). 
Jól látható, hogy az interjúkban arányában kevéssé voltak meghatározók azok a közvetlen állítmány melletti pozíciók, mint amelyek a társalgások esetében annak bizonyultak. Az „egyéb” kategórián belül ugyanakkor további, a szerintem szórendjét illető tendenciák voltak megfigyelhetők (ezek a „,belső”-k összesen egyharmadát tették ki, tehát $\mathrm{kb}$. annyit, mint az alany-állítmány melletti közvetlen előfordulások együttesen!):

- (tag)mondatkezdő alanyi (20 db), tárgyi (3 db) vagy határozói szerepü (10 db) - föként vonatkozó - névmások utáni pozíció (összesen $33 \mathrm{db}$ ) - ez a topik utáni diskurzusjelölö-/kötőszó-használatnak (pl. azonban, mondjuk, egyébként) megfelelő helyzet (lásd a következő alpontot):

(38) Nézze, tehát kettes tanuló ha gimnáziumba megy, az szerintem nem alkotmányossági jog. (MNSz2, 884459179,doc\#2617,spok_hu_radio_020)

- megnyilatkozáskezdő diskurzusjelölő(k) + (alanyi, tárgyi, határozói szerepü) névmás $(10 \mathrm{db})$ vagy névmás + diskurzusjelölő(k) utáni $(4 \mathrm{db})$ pozíció:

(39) Ennek az elöadásnak szerintem az egy nagy titka, hogy a rendezö észrevette, hogy a cím alatt mit ir. Tehát, hogy történik Sevillától nem tudom, hány méterre. És ezt nagyon sokszor elfelejtik, ami szerintem a darabnak egy nagyon fontos kulcsa tehát, hogy pont ebböl a spanyolos temperamentumából tud dolgozni. És ez szerintem hasznára volt az elöadásunknak, ami szerintem egy kicsit jobban sodorta azt, amit úgy lehetett sodorni. (MNSz2, \#931574773,doc\#2648,spok_hu radio_051)

(40) Na most hogyha benézünk itt a kirakaton, márkás cipöt nem látok, az az igazság, hogy börcipöt se látok, csupa müanyag cipöt, amit egyébként szerintem a piacon is meg lehetne vásárolni. (MNSz2, \#861455470,doc\#2602,spok_hu_radio_005)

A belső pozíción belül olyan megoldások is léteztek, amelyek esetében morfológiai természetü (pl. összetett állítmány) (41) vagy szervetlen szókapcsolat (42) tagjai közé került be a szerintem:

(41) ifjabb Tóth György: - De továbbra is magyarul énekelnek.

Eddig is magyarul énekeltünk és nem is fog szerintem megakadályozni semmi ebben. (MNSz2, \#854644708,doc\#2598,spok_hu_radio_001)

(42) Juhászné Galambvári Csilla, a nyíregyházi Humán Net Alapítvány munkatársa: - A roma közösségi ház a Huszár lakótelepen már közel szerintem tíz éve hogy müködik. (MNSz2, \#942179235,doc\#2655,spok_hu_radio_058)

Az értékelő vs. valószínüsítő funkciók tekintetében a társalgásokra vonatkozó elemzésekhez hasonló eredményekre jutottunk: értelmetlennek bizonyult a szétválogatás (pl. a következő három kategóriába: értékelő, valószínűsítő, a kettő valamilyen keveréke), mivel az esetek szinte mind valamilyen fokú keveréknek minősültek (lásd a fenti példákat). 


\section{Konklúziók}

A hipotézisek tesztelése a következő eredményekkel járt: H1a megerősítést nyert: a szerintem mindkét vizsgált müfajban (társalgások, rádióinterjúk) kezdő ( $\mathrm{AK}+\mathrm{K})$, azaz BP-pozícióban volt a leggyakoribb, ezt követte a belső és a záró helyzet. Ez egyrészt igazolja, hogy a diskurzusjelölők alapvetően a BP-t preferálják, ami funkcióikkal (és multifunkcionalitásukkal) jól magyarázható: a téma és a kapcsolt diskurzusszegmens indítását, a vonatkozó beszélői viszonyulást értelemszerűen a közlés (leg)elején célszerü megadni. A nyitás azért is lényegesebb a zárás jelölésénél (ami sokkal ritkábban történik diskurzusjelölővel, mint az előbbi), mert ha a nyitást általában jelöljük, a zárás jelölésére kevésbé vagy nincs szükség: az új nyitás, témaváltás stb. maga azt is jelöli, hogy az előző szegmens lezárult. Feltételezhető, hogy ott jelöljük diskurzusjelölővel a szegmens és a téma befejezését, ahol az valamilyen okból kifolyólag fontosabb vagy egyértelmübbnek kell lennie a szóátadásnak.

$\mathrm{H} 1 \mathrm{~b}$ is igazolódott: a rádióinterjúkban a szerintem valóban kevesebbszer fordult elő belső pozícióban, mint (abszolút) kezdőben vagy záróban. Ennek magyarázatát abban láthatjuk, hogy más beszélt müfajokban is ez a helyzet, tehát a (fél)spontán helyzet nem okvetlenül jár azzal, hogy a belső helyzetü találatok a többi pozíció rovására „túlságosan” felszaporodnak. ${ }^{14}$ Az ugyanakkor önmagában figyelemre méltó, hogy a szerintem nagy arányban (egyharmad előfordulás) jelentkezett a perifériákon kívüli helyzetben. Ekkor sokszor a topikot követő kötőszói jelölőkre jellemző szórendi pozíciókat vette fel.

H2-t egyértelmüen megcáfolták az adatok: a pozíció nem mutatott összefüggést a szerintem két modális alfunkciójával. Az eredmények szerint a modális használatok - szemben a szekvenciális, egyéb retorikai vagy inferenciális szerepekkel nem korlátozódnak az egyes perifériákra. Olyannyira nem, hogy e modális szerepek a szerintem belső pozíciójú változataiban is ugyanúgy egymással valamilyen mértékben összefonódva jelentkeznek, mint a perifériákon.

H3 igazolódott: a szerintem inkább szóátvételkor volt használatos a kezdő határvonal jelölőjeként, semmint szóátadáskor. Hangsúlyozandó azonban, hogy olyan kis mennyiségben jelentkezett fordulónyitáskor és -záráskor, hogy a beszédirányításban játszott szerepe emiatt elenyészőnek mondható. Az interjúkban viszont tipikus volt a fordulókezdő pozíció, amely a már említett müfaji helyzettel (az interjúalany véleményét kérdezik valamely témával kapcsolatban) magyarázható.

A szerintem a relációsság szempontjából átmeneti jelenségnek tűnik: nem kötőszói (eredetü) diskurzusjelölő, de pozíciói sokban megfelelnek azokénak; a propozíció tartozik a hatókörébe, viszont a témairányításban részt vesz (részletesen lásd lentebb).

A szerintem tehát pozíciójától függetlenül mindig kifejez vélekedést (azon belül valószínűsítést és értékelést), az episztenciális modalitás visszaadása a fö szerepe, ehhez a BP-n és JP-n egyéb szekvenciális (kezdő, illetve záró határvonal jelzése,

${ }^{14}$ A két vizsgált müfajra kapott eredményeket szándékosan nem hasonlítom össze egymással, mivel más módszerrel születtek: az első esetében teljes találati mintát elemeztem, a másodikban véletlent. 
témaváltás és -újrakezdés), retorikai (konklúzió, részletezés stb.) és interperszonális (arculatkezelés, egyetértés / egyet nem értés kifejezése) funkciók társulhatnak. A szerintem-et a BP-n és a JP-n nem tarthatjuk más hatókörü és kategóriájú elemnek, mint amikor belső pozíciót vesz fel; annak sem látszik értelme, hogy mindig meglévő modális karaktere miatt „,kettős” hatókörünek tartsuk (BP-n/JP-n diskurzus- és mondatfelettinek, belső helyzetben pedig csak az utóbbinak).

Bár a vizsgálatnak nem volt tárgya a szerintem összes diskurzusjelölői szerepének a bemutatása az elemzett anyagokban, az világos, hogy retorikai és interperszonális funkciókat bármelyik pozícióban elláthat. További tisztázásra szorul azonban, hogy interperszonális szerepei miért nem kapcsolódnak csak a JP-hez (vö. Dér 2020), azt milyen más tényezők befolyásolhatják.

\section{SZAKIRODALOM}

Beeching, Kate - Detges, Ulrich 2014. Introduction. In: Beeching, Kate-Detges, Ulrich (eds.): Discourse functions at the left and right periphery. Crosslinguistic investigation of language use and language change. Brill, Leiden-Boston, 1-23. https://doi. org/10.1163/9789004274822

Boronkai Dóra 2012. A társalgási struktúra mint stílustényező. Interakcionális stilisztikai vizsgálatok a belebonyolódás szakaszában. In: Tátrai Szilárd - Tolcsvai Nagy Gábor (szerk.): A stílus szociokulturális tényezői. Kognitív stilisztikai tanulmányok. ELTE, Budapest, 127-59.

Brown, Penelope - Levinson, Stephen C. 1987. Politeness: Some universals in language usage. Cambridge University Press, Cambridge. https://doi.org/10.1017/CBO9780511813085

Crible, Ludivine 2018. Discourse markers and (dis)fluency. John Benjamins, AmsterdamPhiladelphia. https://doi.org/10.1075/pbns.286

Degand, Lisbeth 2014. So very fast very fast then. Discourse markers at left and right periphery in spoken French. In: Beeching, Kate - Detges, Ulrich (eds): Discourse functions at the left and right periphery. Crosslinguistic investigation of language use and language change. Brill, Leiden-Boston,151-78. https://doi.org/10.1163/9789004274822_008

Degand, Liesbeth - Anne-Marie Simon-Vandenbergen 2011. Grammaticalization and (inter)subjectification of discourse markers. Linguistics 49: 287-94. https://doi.org/10.1515/ ling. 2011.008

Dér Csilla Ilona 2012. Beszélőváltások során használt diskurzusjelölők a magyar spontán beszédben. Beszédkutatás 2012: 130-41.

Dér Csilla Ilona 2016. A szerintem diskurzusjelölő szinkrón és diakrón vizsgálata. In: Reményi Andrea Ágnes - Sárdi Csilla - Tóth Zsuzsa (szerk.): Távlatok a mai magyar alkalmazott nyelvészetben. Tinta Könyvkiadó, Budapest, 474-85.

Dér Csilla Ilona 2018. A szerintem véleményjelölő a magyarban. In: Gecső Tamás - Szabó Mihály (szerk.): Egy-és többértelmüség a nyelvben. Kodolányi János Egyetem-Tinta Könyvkiadó, Székesfehérvár-Budapest, 57-60.

Dér Csilla Ilona 2020. Diskurzusjelölők és társulásaik a magyar nyelvben. KRE-L'Harmattan, Budapest.

Detges, Ulrich - Waltereit, Richard 2014. Moi je ne sais pas vs. Je ne sais pas moi: French disjoint pronouns in the left vs. right periphery. In: Beeching, Kate - Detges, Ulrich (eds): Discourse functions at the left and right periphery. Crosslinguistic investigation of language use and language change. Brill, Leiden-Boston, 24-46. https://doi. org/10.1163/9789004274822_003 
Fraser, Bruce 1999. What are discourse markers? Journal of Pragmatics 31: 931-52. https:// doi.org/10.1016/S0378-2166(98)00101-5

Furkó Bálint Péter 2019. Diskurzusjelölők és egyéb diskurzuspragmatikai eszközök forgatókönyvek, tankönyvek és irodalmi szövegek párbeszédeiben. Debreceni Egyetemi Kiadó, Debrecen.

González, Montserrat 2004. Pragmatic markers in oral narrative. The case of English and Catalan. John Benjamins, Amsterdam-Philadephia. https://doi.org/10.1075/pbns. 122

Gósy Mária - Gyarmathy Dorottya - Horváth Viktória - Gráczi Tekla Etelka - Beke András - Neuberger Tilda - Nikléczy Péter 2012. BEA: Beszélt nyelvi adatbázis. In: Gósy Mária (szerk.): Beszéd, adatbázis, kutatások. Akadémiai Kiadó, Budapest, 9-24.

Haselow Alexander 2012. Discourse organization and the rise of final then in the history of English. In: Hegedüs, Irén - Fodor, Alexandra (eds.): English historical linguistics 2010. Selected papers from the Sixteenth International Conference of English Historical Linguistics (ICEHL 16). Pécs, 23-17 August 2010. John Benjamins, Amsterdam-Philadelphia, 153-75. https://doi.org/10.1075/cilt.325.07has

Hansen, Maj-Britt Mosegaard 1997. Alors and donc in spoken French: A reanalysis. Journal of Pragmatics 28: 153-87. https://doi.org/10.1016/S0378-2166(96)00086-0

É. Kiss Katalin 1992. Az egyszerü mondat szerkezete. In: Kiefer Ferenc (szerk.): Strukturális magyar nyelvtan 1. Mondattan. Akadémiai Kiadó, Budapest, 79-177.

Kugler Nóra 2015. Megfigyelés és következtetés a nyelvi tevékenységben. Tinta Könyvkiadó, Budapest.

Mullan, Kerry 2010. Expressing opinions in French and Australian English Discourse. A semantic and interactional analysis. John Benjamins, Amsterdam-Philadelphia. https:// doi.org/10.1075/pbns.200

Onodera, Noriko O. 2014: Setting up a mental space: A function of discourse markers at the left periphery (LP) and some observations about LP and RP in Japanese. In: Beeching, Kate Detges, Ulrich (eds.): Discourse functions at the left and right periphery. Crosslinguistic investigation of language use and language change. Brill, Leiden-Boston, 92-116. https:// doi.org/10.1163/9789004274822_006

Traugott, Elizabeth Closs 2003. From subjectification to intersubjectification. In: Hickey, Raymond (ed.): Motives for language change. Cambridge University Press, Cambridge, 124-39. https://doi.org/10.1017/CBO9780511486937.009

Traugott, Elizabeth Closs 2012. Intersubjectification and clause periphery. In: Brems, Lieselotte - Ghesquière, Lobke - Van de Velde, Freek (eds.): Intersections of intersubjectivity. Special issue of English Text Construction 5: 7-28. https://doi.org/10.1075/etc.5.1.02trau

Traugott, Elizabeth Closs 2014. On the function of the epistemic adverbs surely and no doubt at the left and right peripheries of the clause. In: Beeching, Kate - Detges, Ulrich (eds.): Discourse functions at the left and right periphery. Crosslinguistic investigation of language use and language change. Brill, Leiden-Boston, 72-91. https://doi. org/10.1163/9789004274822_005

\author{
Dér Csilla Ilona \\ egyetemi docens \\ Károli Gáspar Református Egyetem \\ Magyar Nyelvtudomanyi Tanszék \\ https://orcid.org/0000-0003-2341-7741
}




\title{
SUMMARY
}

\author{
Dér, Csilla Ilona
}

\section{Discourse marker at the periphery? On the positions of the attitude marker szerintem 'in my view' in spoken Hungarian}

This paper discusses the positions and (modal) roles of szerintem 'in my view' as discourse markers (more exactly, attitude markers) in spontaneous conversations and in semi-spontaneous interviews. The study approaches szerintem from other discourse markers typically occurring at discourse peripheries, showing that - albeit this item, too, typically occurs at the left periphery, especially in the material of the interviews - it often occurs in internal position, too, especially in spoken language, where it also takes scope above the whole proposition. The expression of probability and that of evaluation cannot be told apart either with respect to positions or to the genres investigated, the two are intertwined. Although szerintem is most frequently used in initial position, its sequential roles having to do with discourse management (turn taking, taking/yielding the floor) are meagre.

Keywords: periphery, position, scope, discourse marker, attitude marker, spoken language

\section{A lexikai variánsok és az alakpárok kapcsolatrendszere}

\section{Bevezetés}

A Magyar Nyelvőr 144. évfolyam 2. számában megjelent tanulmányunkban (Lőrincz G. - Lőrincz J. 2020) a nyelvi variativitás elméleti kérdéseivel foglalkoztunk. A magyar és a nemzetközi szakirodalom alapján definiáltuk a nyelvi variativitás fogalmát, és ismertettünk néhány - egymástól csak részben eltérő - variánstipológiát, amelyek véleményünk szerint haszonnal alkalmazhatók a kérdéskör további kutatásában. Dolgozatunkban többször jeleztük - az összegzésben pedig nyomatékosan kiemeltük -, hogy az alakváltozatokkal azonos jegyeket (is) mutató lexikológiai jelentésviszonyok, illetve nyelvi jelenségek (pl. részleges alak- és jelentésmegoszlás, szóhasadás, dublettek, konvergens alak- és jelentésfejlödés stb.) részletes elemzése és a variativitástól való elhatárolása önálló keretet kíván, amelyet ez a tanulmány biztosít a hazai és a nemzetközi szakirodalomra építve.

Azt is tisztáztuk, hogy bár a nyelvi variativitás az összes nyelvi szinten megfigyelhetö, a variánsokat érintő legtöbb nyelvészeti kutatás mégis a lexémaszintre összpontosít, ezért ebben az írásban elsősorban mi is ezt vizsgáljuk, már csak azért is, mivel a különböző lexikológiai jelentésviszonyok (amelyek valamelyikébe a legtöbb szóalakpár besorolható) is elsődlegesen ehhez a szinthez kapcsolódnak. Emellett természetesen beszélhetünk például szintaktikai szinonímiáról vagy a toldalékmorfémák homonímiájáról, de ezeknek a jelenségeknek a vizsgálatától ebben a tanulmányban eltekintünk. 